\title{
Sources of sediment carbon sequestered in restored seagrass meadows
}

\author{
J. T. Greiner, G. M. Wilkinson*, K. J. McGlathery, K. A. Emery \\ Department of Environmental Sciences, University of Virginia, Charlottesville, Virginia 22904, USA
}

\begin{abstract}
Seagrass meadows accumulate carbon in sediments as a result of in situ production and sedimentation of particulate organic matter $(\mathrm{OM})$. We quantified the contribution of $\mathrm{OM}$ sources to the sediment carbon pool in restored seagrass meadows of different ages (unvegetated and 4 and 10 yr since restoration) in the Virginia coastal bays. Using carbon (C) and nitrogen (N) stable isotopes, we estimated the contribution of seagrass (Zostera marina), benthic diatoms and sestonic particles (BD/S), and macroalgae (MA) to the sediment OM pool influenced by restoration (top $10 \mathrm{~cm}$ ) with a Bayesian mixing model. Marsh grass was not a likely source based on C:N ratios of the sediment OM. The 4 and $10 \mathrm{yr}$ seagrass meadows had similar OM source contributions to the top $10 \mathrm{~cm}$ of sediment, which were distinct from those of unvegetated sites. Seagrass, BD/S, and MA contributed 41,56 , and $3 \%$, respectively, in the $10 \mathrm{yr}$ age treatments and 50,46, and $4 \%$, respectively, in the $4 \mathrm{yr}$ age treatments. Diagenesis of OM sources had little impact on the source contribution estimates. In combination with carbon accumulation rates at these sites $\left(37 \mathrm{~g} \mathrm{C} \mathrm{m}^{-2}\right.$ $\mathrm{yr}^{-1}$ ), these results indicate that $10 \mathrm{yr}$ after seeding, restored seagrass meadows accumulated seagrass carbon at a rate of $14.3 \mathrm{~g} \mathrm{C} \mathrm{m}^{-2} \mathrm{yr}^{-1}$ and non-seagrass carbon (BD/S and MA) at a rate of $22.4 \mathrm{~g} \mathrm{C} \mathrm{m}^{-2} \mathrm{yr}^{-1}$. This study demonstrates how seagrass restoration contributes to the sequestration of 'blue carbon' and quantifies the impact restored seagrass meadow age has on stored sediment carbon.
\end{abstract}

KEY WORDS: Seagrass $\cdot$ Carbon sequestration $\cdot$ Blue carbon $\cdot$ Stable isotopes

\section{INTRODUCTION}

Seagrass ecosystems are societally and ecologically important because they provide ecosystem services such as increased water quality, biodiversity, habitat, sediment stabilization, and carbon and nutrient accumulation (Hemminga \& Duarte 2000, Orth et al. 2006a, Kennedy et al. 2010, McGlathery et al. 2012, Greiner et al. 2013). Recently, it has been estimated that seagrass meadows accumulate between 48 and

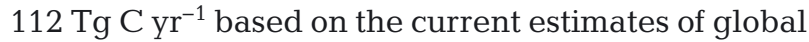
seagrass cover of $177000-600000 \mathrm{~km}^{2}$ (Duarte et al. 2008, Mcleod et al. 2011). The accumulation of carbon in coastal ecosystems, termed 'blue carbon', is a means of mitigating climate change and increased atmospheric carbon dioxide levels (Nellemann et al. 2009, Mcleod et al. 2011, Duarte et al. 2013b). The en-

${ }^{*}$ Corresponding author: gmw6yy@virginia.edu hancement of 'blue carbon' sequestration is possible through the restoration of seagrass meadows (Greiner et al. 2013, Marbà et al. 2015).

The carbon accumulating in seagrass meadows is comprised of autochthonous materials, seagrass materials (leaves, roots, and rhizomes) that are produced and deposited in situ, and allochthonous materials (marsh grass, macroalgae, benthic diatoms, phytoplankton, and seston) that are deposited in the sediment (Gacia \& Duarte 2001, Bouillon \& Boschker 2006, Kennedy et al. 2010). Once carbon accumulates in the seagrass-vegetated sediment it can be preserved on decadal to century time scales (Orem et al. 1999). This is due in part to the seagrass roots and canopy preventing sediment resuspension and to anoxic sediment conditions that reduce microbial decomposition (Koch et al. 2006, Mateo et al. 2006, Duarte et al. 2013a).

(C) The authors 2016. Open Access under Creative Commons by Attribution Licence. Use, distribution and reproduction are unrestricted. Authors and original publication must be credited. 
Seagrass meadows are highly productive systems that produce large amounts of organic carbon. However, the amount and rate of organic carbon accumulating in seagrass sediments often exceeds the amount of carbon produced by seagrass, implying that outside inputs must contribute to carbon stocks in seagrass sediments (Duarte \& Cebrian 1996, Gacia et al. 2002, Duarte et al. 2005, 2010). Based on a review of $>200$ samples from 88 locations, Kennedy et al. (2010) found that on average seagrass contributed about $50 \%$ to the accumulating carbon in sediment and non-seagrass sources, such as phytoplankton, terrestrial plants, and algae, contributed the other half. The input of allochthonous carbon to meadow sediments is likely important in restored beds as many are net heterotrophic (Barrón et al. 2004, Rheuban et al. 2014) and with larger carbon stocks in the sediment than in the aboveground seagrass biomass (McGlathery et al. 2012). However, it is unclear if the carbon stored in restored seagrass meadows comes from the same sources as that stored in natural seagrass meadows.

Stable isotope analysis is a useful tool for determining the different carbon source contributions to the sediment. In multiple-source mixing models, there must be n different tracers, such as stable isotopes, for $\mathrm{n}+1$ contributing organic matter (OM) sources (Phillips $\&$ Gregg 2003). Sources of OM have unique stable isotope ratios due to variability in fractionation and environmental conditions (Fry 1977, 2006, Thayer et al. 1978). As plant species can have analogous photosynthetic pathways resulting in similar fractionation patterns and carbon isotope values, using multiple stable isotopes, such as $\delta^{13} \mathrm{C}\left({ }^{13} \mathrm{C} /{ }^{12} \mathrm{C}\right)$ and $\delta^{15} \mathrm{~N}\left({ }^{15} \mathrm{~N} /{ }^{14} \mathrm{~N}\right)$, is often necessary to distinguish multiple OM sources.

A difficulty in using stable isotopes to quantify OM sources in sediments is that the material is subjected to early diagenesis, primarily through microbial decomposition, which can alter stable isotope values (Freudenthal et al. 2001). The changes associated with the $\delta^{15} \mathrm{~N}$ isotope values of seagrass and macroalgae have the largest potential for variation; in addition, there is little consensus on how much $\delta^{15} \mathrm{~N}$ values change due to diagenesis and in which direction changes occur (Fourqurean \& Schrlau 2003, Machás et al. 2006, Hill \& McQuaid 2009). This is due largely to deamination and substrate composition (Macko \& Estep 1984) and to microbial activity (Zieman et al. 1984). Small changes in the $\delta^{13} \mathrm{C}$ of macroalgae have also been noted with decomposition (Hill \& McQuaid 2009). However, seagrass tissues, especially rhizomes, typically decompose slowly; as a result, studies often assume there is little to no change in the $\delta^{13} \mathrm{C}$ of the seagrass tissue during decomposition (Harrison 1989, Fellerhoff et al. 2003, Papadimitriou et al. 2005a, Kennedy et al. 2010).

The goal of this study was to identify the contributions from seagrass and non-seagrass carbon sources in sediments of restored seagrass meadows of varying age, and to determine if the contributions of each potential carbon source change with meadow age. Sources of OM in seagrass sediments at a large-scale restoration site in the Virginia coastal bays were distinguished using $\delta^{13} \mathrm{C}$ and $\delta^{15} \mathrm{~N}$ in a Bayesian mixing model. Diagenesis was also included in a modified model to determine if there was a significant impact on the final mixing model results. We hypothesized that the seagrass contribution to the OM pool in the restored seagrass meadow would increase with bed age and shoot density.

\section{MATERIALS AND METHODS}

\section{Site description}

This study was conducted at the Virginia Coast Reserve Long Term Ecological Research site (VCRLTER) on the Eastern Shore of Virginia, located on the ocean side of the Delmarva Peninsula. Prior to the 1930s, the VCR supported expansive seagrass meadows in coastal bays; however, the wasting disease and a hurricane in 1933 led to a local extinction of seagrass (Cottam 1934, Rasmussen 1977, Orth et al. 2006b). Now, the VCR is the location of a successful, large-scale restoration of Zostera marina (eelgrass) that was seeded over multiple years beginning in 2001 , with $>1700$ ha of seagrass habitat restored as of 2012 (McGlathery et al. 2012, Orth et al. 2012).

\section{Sediment sampling}

Sediment samples were collected from 2 adjacent locations in the VCR, Hog Island Bay $\left(37^{\circ} 24^{\prime} 47^{\prime \prime} \mathrm{N}\right.$, $\left.75^{\circ} 43^{\prime} 36^{\prime \prime} \mathrm{W}\right)$ and South Bay (37 $15^{\prime} 54^{\prime \prime} \mathrm{N}, 75^{\circ} 48^{\prime}$ $\left.50^{\prime \prime} \mathrm{W}\right)$, both of which are shallow coastal bays with an approximate tidal range of $1.2 \mathrm{~m}$ (McGlathery et al. 2001, 2012). Previous monitoring of these 2 coastal bays determined that bathymetry, sediment, and water characteristics were similar (McGlathery et al. 2012). Sites were seeded in South Bay in 2001 and Hog Island Bay in 2007, creating a chronosequence of '10 $\mathrm{yr}^{\prime}$ and ' $4 \mathrm{yr}^{\prime}$ ' age treatments, respectively. Nearby unvegetated sediments were sampled in addition to the restored seagrass sites as the unre- 
stored, or reference sites (South Bay unvegetated [SBU] and Hog Island Bay unvegetated [HIU]).

Sediments from HIU, 4 yr, and $10 \mathrm{yr}$ age treatments were sampled between June and August 2011, and SBU was sampled in October 2011. Analyses of $20 \mathrm{~cm}$ depth profiles of OM, carbon, and nitrogen content between 24 replicate cores collected for each age treatment (with the exception of 8 replicates at SBU; Greiner et al. 2013) showed no significant differences between replicates for each age treatment. As cores from the same treatment were not significantly different, one $20 \mathrm{~cm}$ deep, $10 \mathrm{~cm}$ diameter core from each age treatment, representative in terms of sediment characteristics, was selected for isotopic analysis. Only the top $10 \mathrm{~cm}$ of sediment was used in this analysis, as previous analysis had demonstrated that sediment below $10 \mathrm{~cm}$ in the 10 yr meadow was deposited prior to restoration efforts (Greiner et al. 2013).

Sediment cores were divided into $1.0 \mathrm{~cm}$ intervals, and shells, rocks, and rhizomes were removed, keeping fine roots in the sediment. The large rhizomes and roots were removed from the sediment cores as the goal of this study was to quantify only carbon accumulation from deposition and fragmentation of autochthonous and allochthonous materials. Previous analysis of the carbon content of the sediment at these sites revealed that the contribution of Zostera roots and rhizomes to the carbon stock in the restored seagrass beds was minimal compared to the particulate carbon in the sediment (Greiner et al. 2013). Subsamples of approximately $10 \mathrm{~g}$ were dried at $60^{\circ} \mathrm{C}$ for $48 \mathrm{~h}$, ground to homogenize, and analyzed for stable isotopes of $\delta^{13} \mathrm{C}$ and $\delta^{15} \mathrm{~N}$. Samples were analyzed using an isotope ratio mass spectrometer at the Colorado Plateau Stable Isotope Laboratory (Flagstaff, AZ). All values are reported in per mil notation (\%) and are relative to the international standards PeeDee Belemnite $\left(\delta^{13} C\right)$ and atmospheric nitrogen $\left(\delta^{15} N\right)$. In the model, the individual $1.0 \mathrm{~cm}$ intervals were combined in a whole core comparison among treatments as well as examined in $0-3,3-6$, and $6-10 \mathrm{~cm}$ intervals. These intervals were selected based on the sedimentation rates in the beds, carbon content in each layer (Greiner et al. 2013), the isotope profiles (see Fig. 1), and the need for replication.

\section{Organic matter sources}

Vegetation samples were categorized into 3 groups: seagrass, benthic diatoms and seston, and macroalgae (Hondula \& Pace 2014). The vegetation samples from Hondula \& Pace (2014) were collected in November
2010-September 2011 at the VCR, overlapping the time frame in which sediment samples were taken. The processing methods of the 2010 and 2011 vegetation are outlined in Hondula \& Pace (2014). The only seagrass species found at this location is eelgrass, Zostera marina $(\mathrm{Z})(\mathrm{n}=14)$ (Table 1$)$. The benthic diatoms were collected using a modified vertical migration technique (Riera \& Richard 1996), and the seston samples were collected by filtering water from seagrass sites onto GF/F filters; these were then dried and analyzed. Phytoplankton biomass is typically low in VCR lagoons, with average annual chl a concentrations ranging between 1 and $6 \mu \mathrm{g} \mathrm{l} \mathrm{l}^{-1}$ (McGlathery et al. 2012); thus, we assumed that seston particles (S) were largely resuspended benthic diatoms (BD) and sediments. The mean $\pm \mathrm{SD}$ values were: $\delta^{13} \mathrm{C}_{\mathrm{BD}}=$ $-20.8 \pm 1.5 \%$ o, $\delta^{15} \mathrm{~N}_{\mathrm{BD}}=6.0 \pm 0.7 \%$ o, $\delta^{13} \mathrm{C}_{\text {Seston }}=24.6 \pm$ $4.3 \%, \delta^{15} \mathrm{~N}_{\text {Seston }}=5.3 \pm 1.2 \%$. The isotope values for $\mathrm{BD}$ and $\mathrm{S}$ were averaged and used to compute the variance used in the analysis as a single source, as they were functionally and isotopically similar ( $\mathrm{n}=$ 25). Macroalgae (MA) samples were comprised of Gracilaria vermicuphylla (mean $\delta^{13} \mathrm{C}=-17.9, \delta^{15} \mathrm{~N}=$ $10.1 ; \mathrm{n}=11)$, Ulva lactuca (mean $\delta^{13} \mathrm{C}=-17.3, \delta^{15} \mathrm{~N}=$ $9.5 ; \mathrm{n}=13)$, Codium fragile (mean $\delta^{13} \mathrm{C}=-15.9, \delta^{15} \mathrm{~N}=$ 10.0; $\mathrm{n}=4$ ), Agardhiella subulata (mean $\delta^{13} \mathrm{C}=-18.8$, $\left.\delta^{15} \mathrm{~N}=9.4 ; \mathrm{n}=3\right)$, Ectocarpus siliculosus $\left(\delta^{13} \mathrm{C}=-16.7\right.$, $\delta^{15} \mathrm{~N}=8.7 ; \mathrm{n}=1$ ), Enteromorpha flexuosa (mean $\left.\delta^{13} \mathrm{C}=-20.1, \delta^{15} \mathrm{~N}=9.2 ; \mathrm{n}=2\right)$, Fucus vesiculosous $\left(\delta^{13} \mathrm{C}=-10.6, \delta^{15} \mathrm{~N}=9.9 ; \mathrm{n}=1\right)$, Polysiphonia nigrescens (mean $\delta^{13} \mathrm{C}=-15.9, \delta^{15} \mathrm{~N}=9.9 ; \mathrm{n}=2$ ), and $S c y$ tosiphon lomentaria (mean $\delta^{13} \mathrm{C}=-14.1, \delta^{15} \mathrm{~N}=8.4$; $\mathrm{n}=2$ ) (Hondula \& Pace 2014). All MA samples were averaged and used to compute the variance in order to be representative of the MA community in the VCR ( $\mathrm{n}=39$ ) (Thomsen et al. 2006).

Additional samples of seagrass, Gracilaria spp., and Ulva spp. were collected from the VCR in June 2013 for a time series diagenesis experiment (described in the following subsection). These species represent $>90 \%$ of the macroalgal biomass at the sites (Thomsen et al. 2006). The initial time point vegetation samples for this experiment (pre-diagenesis) were combined with the other vegetation samples as they were not isotopically different from the 2010 and 2011 samples (included in the means reported above). All vegetation samples were processed by rinsing, removing epiphytic material, drying at $60^{\circ} \mathrm{C}$ for $48 \mathrm{~h}$, and grinding to homogenize. Samples were encapsulated in tin capsules for $\delta^{13} \mathrm{C}$ and $\delta^{15} \mathrm{~N}$ stable isotope analysis at the Colorado Plateau Stable Isotope Laboratory following the same procedure as the sediment samples. 


\section{Diagenesis values}

A litterbag experiment was conducted to determine the impact of diagenesis on the stable isotope values $\left(\delta^{13} \mathrm{C}\right.$ and $\left.\delta^{15} \mathrm{~N}\right)$ of potential sediment OM sources. The 2 dominant macroalgae (Gracilaria spp. and Ulva spp.) and 1 seagrass (Zostera marina) species were collected from South Bay and adjacent marshes and mudflats in June 2013. Epiphytic material was removed, and samples were rinsed with deionized water prior to enclosure in litterbags ( $1 \mathrm{~mm}$ mesh) and drying at $60^{\circ} \mathrm{C}$ for $48 \mathrm{~h}$. Litterbags were suspended in flow-through seawater mesocosms for $28 \mathrm{~d}$ (macroalgae) or $56 \mathrm{~d}$ (seagrass). The macroalgal experiment was terminated at $28 \mathrm{~d}$ in order to have enough material for isotope analysis. Three replicates of each fresh sample were used to represent initial ( $t=0)$ conditions, and 3 litterbags were used to replicate degraded conditions ( $t=28$ or 56). A diagenesis term based on net change $(\Delta)$ in $\delta$ values from initial values was incorporated into the modified diagenesis model presented below.

\section{Mixing model}

The sediment $\delta^{13} \mathrm{C}$ value $\left(\delta^{13} \mathrm{C}_{\text {sed }}\right)$ is a function of the contribution of the inorganic (IC) and organic carbon (OC) isotope components in that:

$$
\begin{aligned}
& \delta^{13} \mathrm{C}_{\mathrm{sed}}=\left(\phi_{\mathrm{IC}} \times \delta^{13} \mathrm{C}_{\mathrm{IC}}\right)+\left(\phi_{\mathrm{OC}} \times \delta^{13} \mathrm{C}_{\mathrm{OC}}\right) \\
& 1=\phi_{\mathrm{IC}}+\phi_{\mathrm{OC}}
\end{aligned}
$$

where $\phi$ is the proportional contribution of each source to the sediment. The IC component, measured as the difference in \% $\mathrm{C}$ before and after acidification, is $4.9 \pm 9 \%$ in these sediments, and the $\delta^{13} \mathrm{C}_{\mathrm{IC}}$ was set at $-1 \%$ (Fry 2006). The OC component can be further divided into macroalgae, seagrass, and benthic microalgae. Using the stable isotope ratios, a 3 -source $\left(\mathrm{Z}, \mathrm{BD} / \mathrm{S}\right.$, and MA) 2-tracer $\left(\delta^{13} \mathrm{C}\right.$ and $\left.\delta^{15} \mathrm{~N}\right)$ Bayesian mixing model was used to quantify the proportional contribution of each OM source to the sediment at each site (HIU, $4 \mathrm{yr}, \mathrm{SBU}$, and $10 \mathrm{yr}$ ). A Bayesian framework allows for the inclusion of multiple sources of uncertainty combined with prior information to determine the maximum likelihood of a solution, expressed as a posterior distribution (Moore \& Semmens 2008, Semmens et al. 2009). Other model runs including a third tracer, the $\mathrm{C}: \mathrm{N}$ ratio, concluded that the dominant marsh grass in the area, Spartina alterniflora, was not a large contributor $(<10 \%)$ to the sediment carbon pool (see the Supple- ment at www.int-res.com/articles/suppl/m551p095_ supp.pdf for model details and results). Source endmember contributions to the sediment were estimated using the following equations:

$$
\begin{aligned}
& \delta^{13} \mathrm{C}_{\mathrm{sed}}=\left(\left(\delta^{13} \mathrm{C}_{\mathrm{Z}} \times \phi_{\mathrm{Z}}\right)+\left(\delta^{13} \mathrm{C}_{\mathrm{MA}} \times \phi_{\mathrm{MA}}\right)+\left(\delta^{13} \mathrm{C}_{\mathrm{BD} / \mathrm{S}} \times \phi_{\mathrm{BD} / \mathrm{S}}\right)\right) \\
& \times\left(1-\phi_{\mathrm{IC}}\right)+\left(\delta^{13} \mathrm{C}_{\mathrm{IC}} \times \phi_{\mathrm{IC}}\right) \\
& \delta^{15} \mathrm{~N}_{\mathrm{sed}}=\left(\delta^{15} \mathrm{~N}_{\mathrm{Z}} \times \phi_{\mathrm{Z}}\right)+\left(\delta^{15} \mathrm{~N}_{\mathrm{MA}} \times \phi_{\mathrm{MA}}\right)+\left(\delta^{15} \mathrm{~N}_{\mathrm{BD} / \mathrm{S}} \times \phi_{\mathrm{BD} / \mathrm{S}}\right) \\
& 1=\phi_{\mathrm{Z}}+\phi_{\mathrm{MA}}+\phi_{\mathrm{BD} / \mathrm{S}}
\end{aligned}
$$

in which $\delta^{13} \mathrm{C}$ and $\delta^{15} \mathrm{~N}$ were the measured stable isotope values of the sediment and the potential sources $(\mathrm{Z}, \mathrm{BD} / \mathrm{S}$, and $\mathrm{MA})$. Sediment isotope ratios were analyzed by both combining the top $10 \mathrm{~cm}$ samples, and separately considering the $0-3,3-6$, and 6$10 \mathrm{~cm}$ depth intervals. The uninformative prior probability distributions of the source portions were center-log transformed (Semmens et al. 2009), and all calculations were done using Just Another Gibbs Sampler (JAGS) in R (R Core Team 2012). This model is a modification of the multiple isotope mixing model presented in Solomon et al. (2011) and Wilkinson et al. (2013). The posterior distributions of the OM sources were reported using median and quartile values (5th, 25th, 75th, and 95th). Percent differences of OM source proportions were calculated between all mixing model source iterations using median values from each depth interval $(0-3,3-6$, 6-10 cm). A modified mixing model incorporating OM diagenesis was used to evaluate the contribution of OM sources to the sediment using the following equations:

$$
\begin{aligned}
\delta^{13} \mathrm{C}_{\mathrm{sed}}= & \left(\left(\left(\delta^{13} \mathrm{C}_{\mathrm{Z}}+\Delta \mathrm{C}_{\mathrm{Z}}\right) \times \phi_{\mathrm{Z}}\right)+\left(\left(\delta^{13} \mathrm{C}_{\mathrm{MA}}+\Delta \mathrm{C}_{\mathrm{MA}}\right) \times \phi_{\mathrm{MA}}\right)\right. \\
& \left.+\left(\left(\delta^{13} \mathrm{C}_{\mathrm{BD} / \mathrm{S}}+\Delta \mathrm{C}_{\mathrm{BD} / \mathrm{S}}\right) \times \phi_{\mathrm{BD} / \mathrm{S}}\right)\right) \times\left(1-\phi_{\mathrm{IC}}\right) \\
& +\left(\delta^{13} \mathrm{C}_{\mathrm{IC}} \times \phi_{\mathrm{IC}}\right) \\
\delta^{15} \mathrm{~N}_{\mathrm{sed}}= & \left(\left(\delta^{15} \mathrm{~N}_{\mathrm{Z}}+\Delta \mathrm{N}_{\mathrm{Z}}\right) \times \phi_{\mathrm{Z}}\right)+\left(\left(\delta^{15} \mathrm{~N}_{\mathrm{MA}}+\Delta \mathrm{N}_{\mathrm{MA}}\right) \times \phi_{\mathrm{MA}}\right) \\
& +\left(\left(\delta^{15} \mathrm{~N}_{\mathrm{BD} / \mathrm{S}}+\Delta \mathrm{N}_{\mathrm{BD} / \mathrm{S}}\right) \times \phi_{\mathrm{BD} / \mathrm{S}}\right) \\
1=\phi_{\mathrm{Z}}+ & \phi_{\mathrm{MA}}+\phi_{\mathrm{BD} / \mathrm{S}}
\end{aligned}
$$

where $\Delta$ is the change in the stable isotope values from the diagenesis experiments described above (see Table 2). The measured OM source isotope value was modified by adding the diagenesis effect. The mean and precision of $\Delta$ were used in the model, and the priors of the source portions were treated as described above in the model. The results of the original and modified Bayesian mixing models were then evaluated to determine the effect of including diagenesis on the final source portion estimates. 


\section{RESULTS}

\section{Sediment isotope values}

There were variations in $\delta^{13} \mathrm{C}$ and $\delta^{15} \mathrm{~N}$ values over depth and among age treatments in the top $10 \mathrm{~cm}$ of sediment. The unvegetated sites (HIU and SBU) had different $\delta^{13} \mathrm{C}$ profiles between the two sites, with more negative $\delta^{13} \mathrm{C}$ values in $\mathrm{HIU}$ (Fig. 1A). In the vegetated sites, the $10 \mathrm{yr}$ site was less negative in the $\delta^{13} \mathrm{C}$ sediment profile than the $4 \mathrm{yr}$ and HIU sites (Fig. 1A). The difference in average $\delta^{13} \mathrm{C}$ in the top $10 \mathrm{~cm}$ of sediment between the vegetated site and each neighboring unvegetated site was $>2 \%$, but there was a smaller difference between the $4 \mathrm{yr}$ and $10 \mathrm{yr}$ sites (Table 1). The SBU site was generally more depleted in $\delta^{15} \mathrm{~N}$ compared to the other sites (Fig. 1B). There was little difference $(0.1 \%$ ) between the vegetated sites and their neighboring unvegetated sites for the average $\delta^{15} \mathrm{~N}$ of the top $10 \mathrm{~cm}$ of sediment and a greater difference between the 4 yr and $10 \mathrm{yr}$ sites (Table 1).

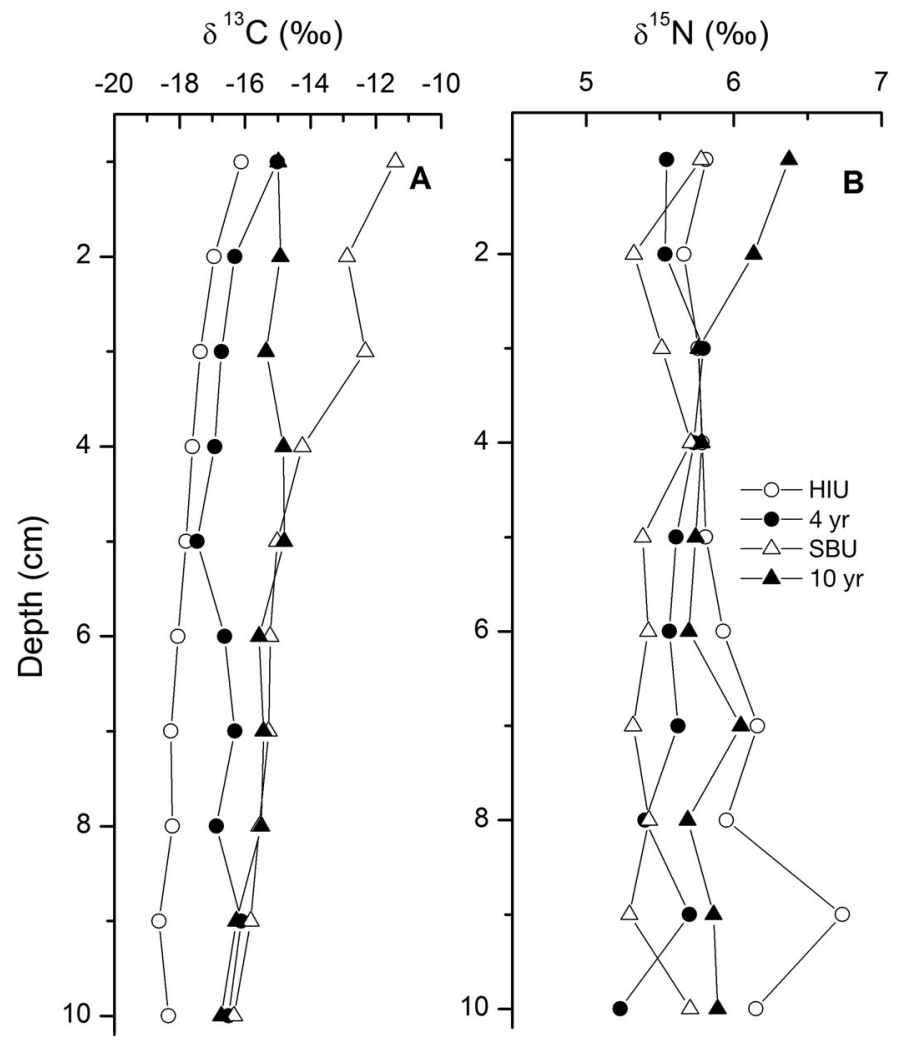

Fig. 1. Vertical profiles of sediment isotope values for 4 different sites (unvegetated sediment in Hog Island Bay [HIU], 4 yr restored seagrass treatment in Hog Island Bay [4 yr], unvegetated sediment in South Bay [SBU], and 10 yr restored seagrass treatment in South Bay [10 yr]) in the top $10 \mathrm{~cm}$ of sediment $\left(1 \mathrm{~cm}\right.$ intervals): (A) $\delta^{13} \mathrm{C}(\%)$ and (B) $\delta^{15} \mathrm{~N}(\%)$. The isotope profiles are from one sediment core
All of the sediment isotope values fell within the bounds of the end-member isotope values (Fig. 2A). There was a clear separation of values between $\mathrm{Z}$, $\mathrm{BD} / \mathrm{S}$, and MA with $\delta^{13} \mathrm{C}$ and a clear separation of $\mathrm{MA}$ from $\mathrm{Z}$ and BD/S with $\delta^{15} \mathrm{~N}$. Even with the influence of diagenesis (Table 2), sediment isotope values from vegetated sites remained within the bounds of the end-member isotope values (Fig. 2B).

\section{Mixing model results}

$\mathrm{Z}$ and $\mathrm{BD} / \mathrm{S}$ sources contributed the most to sediment $\mathrm{OM}$ in the vegetated and unvegetated sediments. All percent contributions are reported as the mean of the posterior distributions (Fig. 3). At the HIU site, $\mathrm{Z}$ and $\mathrm{BD} / \mathrm{S}$ contributed 29 and $64 \%$, respectively (Fig. 3A), while the contribution of $\mathrm{Z}$ and $\mathrm{BD} / \mathrm{S}$ at the SBU site was more even (52 and $46 \%$, respectively) (Fig. 3C). At the 4 yr site, $\mathrm{Z}$ contributed $50 \%$ to sediment $\mathrm{OM}$ and $\mathrm{BD} / \mathrm{S}$ contributed $46 \%$

Table 1. Carbon and nitrogen source and sediment averages (mean), standard deviations $( \pm \mathrm{SD})$, and sample size $(\mathrm{n})$ for $\delta^{13} \mathrm{C}$ and $\delta^{15} \mathrm{~N}$ values used in a 3 -source, 2-tracer Bayesian mixing model. Each sediment treatment (HIU, 4 yr, SBU, and $10 \mathrm{yr}$, for definitions see Fig. 1) was averaged for the top 10, $0-3,3-6$, and $6-10 \mathrm{~cm}$ of sediment. Organic matter sources include Zostera marina (Z), benthic diatoms and sestonic particles (BD/S), and multiple macroalgae species (MA)

\begin{tabular}{|lcrlll|}
\hline \multirow{2}{*}{ Source } & $\mathrm{n}$ & \multicolumn{2}{c}{$\delta^{13} \mathrm{C}$} & \multicolumn{2}{c|}{$\delta^{15} \mathrm{~N}$} \\
& & Mean & $\pm \mathrm{SD}$ & Mean & $\pm \mathrm{SD}$ \\
\hline $\mathrm{Z}$ & 14 & -9.9 & 0.5 & 6.7 & 0.5 \\
$\mathrm{BD} / \mathrm{S}$ & 25 & -23.3 & 2.17 & 5.6 & 1.2 \\
$\mathrm{MA}$ & 39 & -17.2 & 3.3 & 9.6 & 1.5 \\
$\mathbf{0 - 1 0} \mathbf{~ c m}$ & & & & & \\
$\mathrm{HIU}$ & 10 & -17.7 & 0.8 & 6.0 & 0.3 \\
4 yr & 10 & -15.4 & 0.6 & 5.9 & 0.2 \\
SBU & 10 & -14.4 & 1.7 & 5.5 & 0.2 \\
10 yr & 10 & -16.5 & 0.6 & 5.6 & 0.2 \\
$\mathbf{0 - 3} \mathbf{~ c m}$ & & & & & \\
$\mathrm{HIU}$ & 3 & -16.8 & 0.6 & 5.8 & 0.1 \\
4 yr & 3 & -15.1 & 0.2 & 6.1 & 0.3 \\
SBU & 3 & -12.2 & 0.8 & 5.5 & 0.2 \\
10 yr & 3 & -16.0 & 0.9 & 5.6 & 0.2 \\
$\mathbf{3 - 6} \mathbf{~ c m}$ & & & & & \\
HIU & 3 & -17.8 & 0.2 & 5.8 & 0.1 \\
4 yr & 3 & -15.1 & 0.4 & 5.7 & 0.0 \\
SBU & 3 & -14.8 & 0.5 & 5.5 & 0.2 \\
10 yr & 3 & -17.0 & 0.4 & 5.6 & 0.1 \\
$\mathbf{6 - 1 0} \mathbf{~ c m ~}$ & & & & & \\
HIU & 4 & -18.4 & 0.2 & 6.3 & 0.3 \\
4 yr & 4 & -16.0 & 0.6 & 5.9 & 0.2 \\
SBU & 4 & -15.8 & 0.5 & 5.4 & 0.2 \\
10 yr & 4 & -16.5 & 0.3 & 5.5 & 0.2 \\
& & & & & \\
\hline
\end{tabular}



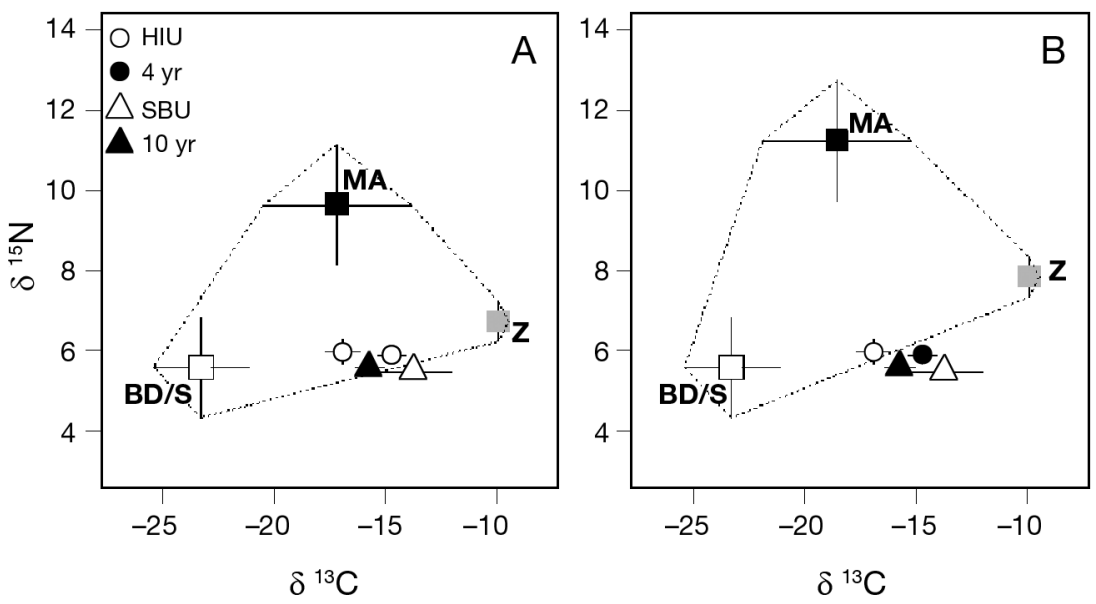

Fig. 2. Bi-plots of $\delta^{13} \mathrm{C}$ and $\delta^{15} \mathrm{~N}$ values of sediment treatments and source materials. The average end-member values, Zostera marina (Z), benthic diatoms and sestonic particles (BD/S), and macroalgae (MA) are plotted (squares) with (A) the average sediment values from the 4 different treatments (HIU, 4 yr, SBU, and $10 \mathrm{yr}$ ) and (B) the average sediment and source values including diagenesis effects to sources. All sediment carbon values have been corrected for inorganic carbon contribution. Error bars are standard deviations; the dashed line is the source polygon bounding the isotope mixing space. Treatment abbreviations, see Fig. 1

Table 2. Mean change in $\delta^{13} \mathrm{C}$ and $\delta^{15} \mathrm{~N}$ (SE) of end members during the diagenesis experiment. Values were used in the diagenesis model. Mass loss during the experiments (reported as a percentage), duration of the incubation, and the decay constant (k) are also presented

\begin{tabular}{|c|c|c|c|c|c|}
\hline Source material & Change in $\delta^{13} \mathrm{C}$ & Change in $\delta^{15} \mathrm{~N}$ & Percent mass loss & $\mathrm{k}$ & $\begin{array}{l}\text { Duration of incubation } \\
\text { (d) }\end{array}$ \\
\hline Zostera marina & $0.02(0.02)$ & $1.09(0.03)$ & $64.2(0.9)$ & 0.019 & 56 \\
\hline Spartina alterniflora & $0.22(0.05)$ & $1.49(0.50)$ & $85.7(1.1)$ & 0.035 & 56 \\
\hline Ulva lactuca & $-1.49(0.24)$ & $-1.42(0.10)$ & $83.8(1.5)$ & 0.065 & 28 \\
\hline Gracilaria vermiculophylla & $-1.26(0.23)$ & $-1.7(0.33)$ & $99.2(0.5)$ & 0.137 & 28 \\
\hline
\end{tabular}
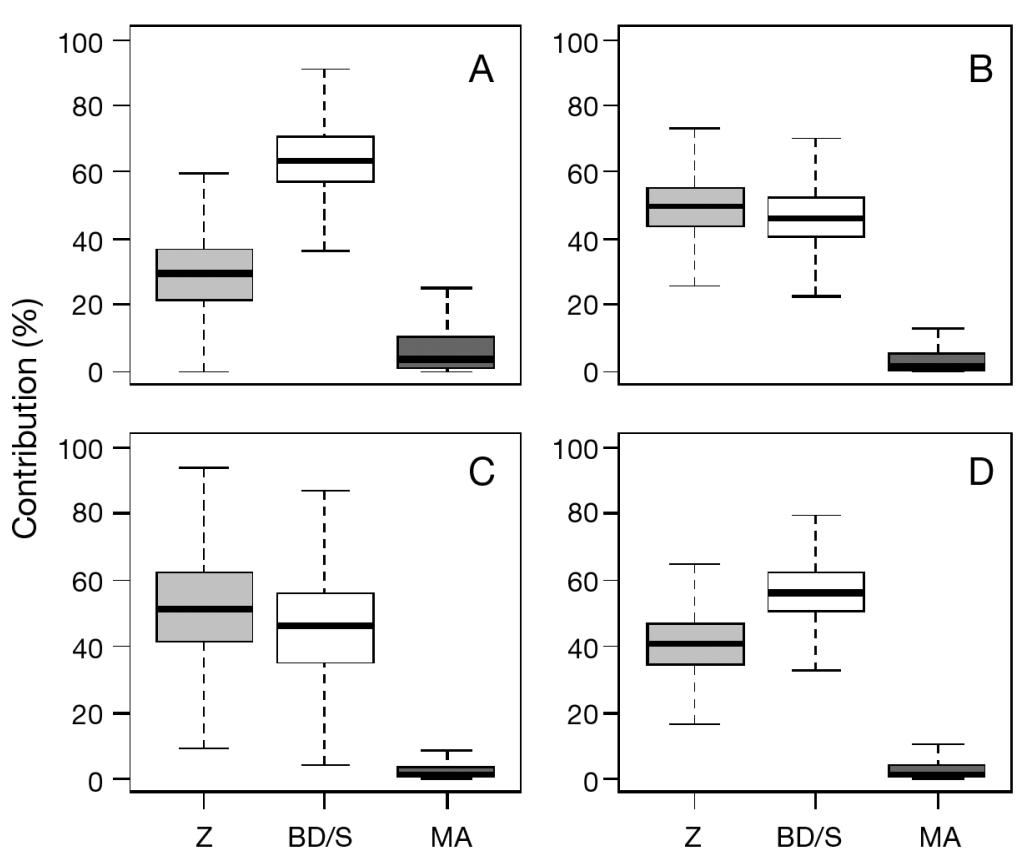

(Fig. 3B). Lastly, the $10 \mathrm{yr}$ site had $41 \% \mathrm{Z}$ contribution and $56 \%$ BD/S (Fig. 3D). The remaining contributing OM source material was macroalgae, which ranged between 3 and $7 \%$ among sites (Fig. 3).

Cores were divided into intervals of the top $0-3,3-6$, and $6-10 \mathrm{~cm}$ to show trends within the sediment cores and to compare sections across different age treatments. These intervals of sediment stable isotope values showed clear patterns and differences (Table 1). In general, at all sites, the relative contribution of seagrass to the sediment carbon stock decreased with depth (Fig. 4). Z contributed the most (77\%) to the top $3 \mathrm{~cm}$ of unvegetated sediment at the $10 \mathrm{yr}$ site (SBU) and the least (38\%) to the top $3 \mathrm{~cm}$ of the $4 \mathrm{yr}$ site (HIU). The BD/S contributions typically increased with core depth, whereas MA contributions were consistently low thoughout the core $1<5 \%$ except for the 6-10 cm depth of HIU where the MA contribution was $11 \%$ ).

The modified diagenesis model decreased the contribution of Z by approximately $7.7 \%$ of each source (Z: light gray; BD/S: white; MA: dark gray) to the sediment (top $10 \mathrm{~cm}$ of sediment): (A) HIU, (B) $4 \mathrm{yr}$, (C) SBU, and (D) $10 \mathrm{yr}$. Midline: median; box limits: 25 th and 75 th percentiles; whiskers: 5 th and 95th percentiles. Abbreviations: see Figs. 1 \& 2 

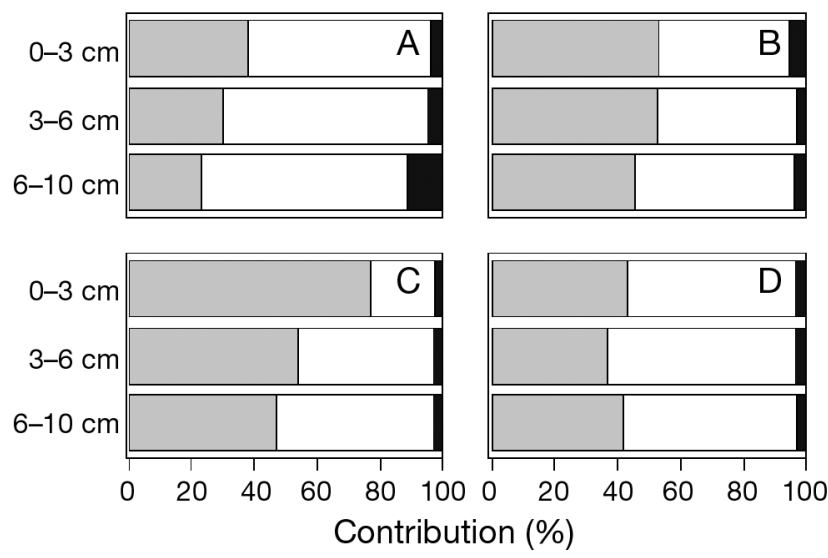

Fig. 4. Mean percent contribution of the posterior distributions to each sediment treatment in down-core intervals ( $\mathrm{Z}$ : light gray; BD/S: white; MA: black): (A) HIU, (B) 4 yr, (C) SBU, and (D) 10 yr. Abbreviations see Figs. 1 \& 2

across sites, with a concurrent increase in the contribution of $\mathrm{BD} / \mathrm{S}$ and MA (Fig. 5). For the SBU site, including diagenesis resulted in a $17 \%$ decrease in the $\mathrm{Z}$ contribution and a $15 \%$ increase in the $\mathrm{BD} / \mathrm{S}$ contribution. When the sediment core was divided by $3 \mathrm{~cm}$ intervals as in Fig. 4, the change in the $\mathrm{Z}$ contribution in the $0-3 \mathrm{~cm}$ interval with diagenesis included was similar to the whole-core patterns and magnitude (approximately 6\%). The change in the other segments was smaller (approximately $4 \%$ ). Though the OM fractional contributions changed

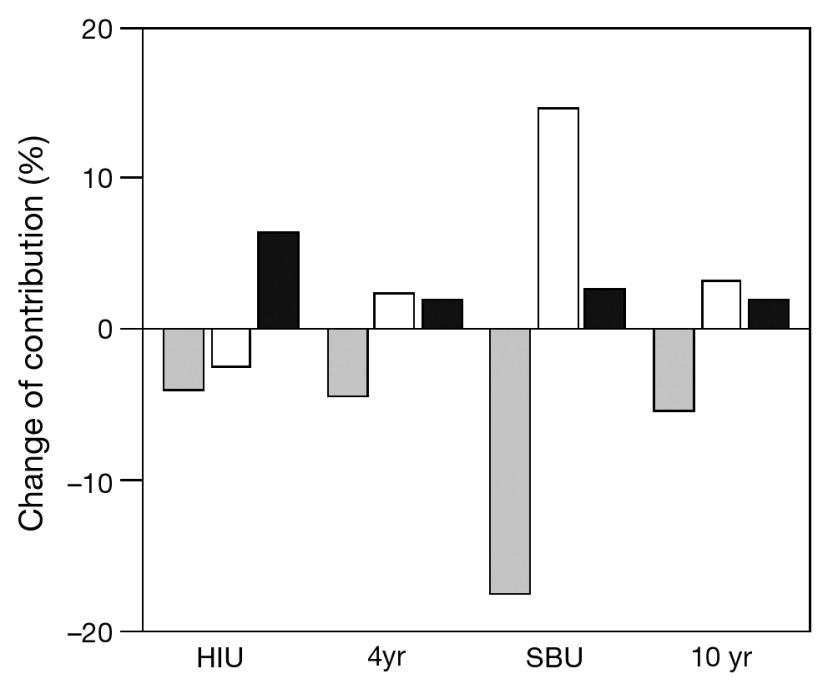

Fig. 5. Change in the mean of the posterior distribution of each source (Z: light gray; BD/S: white; MA: dark gray) between the original mixing model and the modified diagenesis mixing model for the top $10 \mathrm{~cm}$ of sediment. Abbreviations: see Figs. 1 \& 2 when diagenesis was considered, the $\mathrm{Z}$ contribution pattern among sites did not change.

\section{DISCUSSION}

Seagrass (Z) and BD/S were the dominant contributors to sediment $\mathrm{OM}$ in all age treatments in the restored meadows. Seagrass contributed between 29 and $52 \%$, and $\mathrm{BD} / \mathrm{S}$ contributed between 45 and $64 \%$ (Fig. 3). The contribution of seagrass to sediment OM pools was similar to reported literature values of $29 \%$ (Thayer et al. 1978) and $50 \%$ (Kennedy et al. 2010) in natural meadows. Gonneea et al. (2004) also measured carbon source contributions to seagrass-vegetated sediment and found that phytoplankton and seston contributed variable amounts to accumulated carbon (20-80\%), while seagrass (Halodule wrightii, Ruppia sp., Thalassia testudinum) contributed approximately $30 \%$, and the remaining contribution $(20-70 \%)$ came from terrestrial sources such as mangroves. However, in the restored seagrass beds of the VCR, terrestrial sources such as marsh grass contributed little (see the Supplement), as did macroalgae.

The importance of seagrass to sediment carbon pools varied between the unvegetated sites, and this was likely the result of both proximity to the meadows and seagrass shoot density. At the HIU site, the contribution of seagrass carbon was $38 \%$ in the top 3 $\mathrm{cm}$ of the sediment (Fig. 4A). This is likely due to low seagrass densities in the $4 \mathrm{yr}$ treatment that were adjacent to the HI unvegetated area. Interestingly, the SBU site neighboring the $10 \mathrm{yr}$ treatment had a high contribution of seagrass $(77 \%)$ to stored carbon in the top $3 \mathrm{~cm}$ of sediment (Fig. $4 \mathrm{C}$ ). This may be the result of exported seagrass wrack from the dense $10 \mathrm{yr}$ meadow to nearby unvegetated areas (McGlathery et al. 2012, Orth et al. 2012). The SBU site was closer to the meadow edge than the HIU site, and the probability of seagrass OM being transported to the unvegetated sites by currents is likely higher. Concentrations of OM were low in VCR sediments, and so the addition of a small amount of seagrass wrack at the unvegetated site could greatly impact the proportion of OM in the sediment core from seagrass. The results illustrate how restored seagrass meadows potentially impact sediment OM beyond the seagrass meadow bounds.

The relative contribution of benthic diatoms and seston to sediment carbon accumulation was also highly variable, and accounted for roughly half to two-thirds of the carbon pool in all sediments. This is 
consistent both with the high benthic chlorophyll concentrations in the VCR lagoons (McGlathery et al. 2008,2012 ) and with the origination of benthic diatoms and seston in seagrass and vegetated sediments (Middelburg et al. 2000, Mateo et al. 2006). The BD/S contribution increased with depth in the sediment profile, likely due to the fact that benthic diatoms and seston were the main sources of carbon to the sediment before seagrass recolonization (Greiner et al. 2013). The minimal contribution of MA to the top $10 \mathrm{~cm}$ of sediment OM across all treatments $(\leq 1 \%)$ is consistent with the patchy distribution of MA at the sites and suggests that MA do not accumulate for a sufficient time for detritus to become incorporated into the sediments. The $\mathrm{BD} / \mathrm{S}$ contribution increased with depth in the sediment profile, likely due to the fact that benthic diatoms and seston were the main sources of carbon to the sediment before seagrass recolonization (Greiner et al. 2013).

\section{Organic matter source considerations}

The isotopic carbon and nitrogen values of seagrass can vary depending on which parts (epiphytes, leaves, roots, or rhizomes) of the plant are analyzed and the time at which vegetation is sampled. There has been debate over whether to include epiphytes in seagrass isotopic analyses. We excluded epiphytes in our analysis based on literature reports of the small impact of epiphytes on seagrass isotope values and the low epiphyte biomass at our sites (Papadimitriou et al. 2005a, Kennedy et al. 2010). Seagrass epiphytes may in fact be more similar isotopically to the $\mathrm{BD} / \mathrm{S}$ end member; therefore, the $\mathrm{BD} / \mathrm{S}$ isotope values likely include epiphytes to some degree and are incorporated as a contributing OM source (Dubois et al. 2012). Seagrass roots and rhizomes are also important source materials that can differ from seagrass isotope values due to slower decomposition rates (Fourqurean \& Schrlau 2003). The present study includes fine seagrass roots in sediment samples, which did not impact the carbon stock in either vegetated meadows (Greiner et al. 2013). In addition, Papadimitriou et al. (2005b) found no significant difference between the leaves and rhizomes of seagrass with respect to $\delta^{13} \mathrm{C}$ or $\delta^{15} \mathrm{~N}$.

With only 2 isotope tracers, the estimate of OM source contributions was limited to 3 potential sources; however, marsh grass is another potential carbon source. In a separate analysis using molar $\mathrm{C}: \mathrm{N}$ as a third tracer, marsh grass contributed $<10 \%$ to the sediment carbon stock (see the Supplement for further methods and details). Although marsh grass was not a large contributor to the sediment sampled in these particular locations, it could be a large source of carbon closer to the marsh edge if there is a spatial gradient in source contributions. Spatial variability in sediment carbon content and sources requires further study (Gonneea et al. 2004, Ricart et al. 2015) and would benefit from the addition of other tracers, such as sulfur stable isotopes (Peterson \& Howarth 1987).

Additionally, stable isotope values down-core can be variably impacted by diagenesis. The impact of diagenesis on stable isotopes in marine sediments is due to variations in substrate, anoxic or oxic environments, and source materials (Freudenthal et al. 2001). The diagenesis values estimated in this study reflect the isotopic changes during early aerobic decomposition, although $>80 \%$ of the original material was decomposed and decomposition rates were similar to other published values for these organisms (Harrison 1989, Castaldelli et al. 2003). The changes were small and did not substantially change endmember isotope values or patterns among sites and down-core within a site at all sites but the SBU (Figs. 2B \& 5). The large difference in the SBU site could be the result of a large seagrass input into the sediment at that location. Anaerobic decomposition in the anoxic sediments could also contribute to changes in the stable isotope ratios; however, anaerobic decomposition was likely minimal over the time scale considered in this study. The general results of stable isotope ratios not changing significantly with diagenesis are consistent with other systems with similarly low levels of sediment OM (Meyers \& Ishiwatari 1993, Gonneea et al. 2004).

\section{Carbon accumulation and sources}

Dense and established seagrass meadows accumulate and store carbon on long (decadal to century) time scales, as the dense canopy prevents resuspension of surface and deeper sediment (Koch et al. 2006, Hansen \& Reidenbach 2013). The 'blue carbon' sequestration capacity of seagrass meadows may be lost with habitat degradation worldwide (Pendleton et al. 2012), but restoration can reinstate this important ecosystem service (McGlathery et al. 2012, Greiner et al. 2013, Marbà et al. 2015). In the Virginia coastal bays, a rapid increase in shoot density occurred 4 yr after seeding (McGlathery et al. 2012), and, after approximately $5 \mathrm{yr}$, the restored seagrass meadow began to accumulate measurable carbon in 
the sediment (Greiner et al. 2013). Seagrass contribution to sediment carbon was higher in the $4 \mathrm{yr}$ than in the $10 \mathrm{yr}$ treatment throughout the entire core (Fig. 4B,D). The increased seagrass carbon contribution in the 4 yr treatment was consistent with dating results from Greiner et al. (2013) indicating that $5 \mathrm{yr}$ after restoration the increase in carbon accumulation was from a different carbon source, e.g. BD/S. It was hypothesized that over time the carbon sources would change from a high percent of $\mathrm{C}$ by volume (seagrass) to a low percent of $\mathrm{C}$ (BD/S particles) due to increased particle trapping with increased seagrass shoot density (Greiner et al. 2013). The $4 \mathrm{yr}$ meadow had an average of 123.2 shoots $\mathrm{m}^{-2}$ and the 10 yr meadow had an average of 428.7 shoots $\mathrm{m}^{-2}$ (Greiner et al. 2013); thus, the 10 yr meadow was more likely to have sediment carbon comprised of imported BD/S trapped by the denser seagrass. This is consistent with the greater observed BD/S contribution to the sediment at the $10 \mathrm{yr}$ site compared to the 4 yr site. This hypothesis was also supported by the results of Marbà et al. (2015), as similar trends were found: when the seagrass was restored, the accumulation of allochthonous carbon, such as sestonic particles, was also restored.

Combining carbon accumulation rates with fractional source contributions provides essential information on coastal carbon cycling. Previous research at the VCR found that the $10 \mathrm{yr}$ restored seagrass meadow accumulated carbon at a rate of $36.7 \mathrm{~g} \mathrm{C} \mathrm{m}^{-2}$ $\mathrm{yr}^{-1}$ (Greiner et al. 2013), which is slightly higher than the $26.4 \mathrm{~g} \mathrm{C} \mathrm{m}^{-2} \mathrm{yr}^{-1}$ in a restored seagrass meadow in western Australia (Marbà et al. 2015). Twelve years after seeding the restored VCR meadow was projected to accumulate carbon at rates similar to those of natural seagrass meadows (45$190 \mathrm{~g} \mathrm{C} \mathrm{m}^{-2} \mathrm{yr}^{-1}$; Mcleod et al. 2011). By combining the carbon accumulation rate with carbon source contributions, the restored $10 \mathrm{yr}$ seagrass sediment accumulated about $14.3 \mathrm{~g} \mathrm{C} \mathrm{m}^{-2} \mathrm{yr}^{-1}$ from seagrass and the remaining $22.4 \mathrm{~g} \mathrm{C} \mathrm{m}^{-2} \mathrm{yr}^{-1}$ from non-seagrass sources (primarily BD/S) in the top $3 \mathrm{~cm}$. This study demonstrates that restored seagrass meadows are an important sink of 'blue carbon' for the lagoon system as a whole, as $10 \mathrm{yr}$ after restoration the meadows were accumulating carbon from both seagrass and non-seagrass sources.

Acknowledgements. We thank the research staff at the University of Virginia's Anheuser-Busch Coastal Research Center for providing assistance, and the reviewers for improving the manuscript. Funding was provided by the National Science Foundation grants DEB-0621014 and DEB-1237733.

\section{LITERATURE CITED}

Barrón C, Marbà N, Terrados J, Kennedy H, Duarte CM (2004) Community metabolism and carbon budget along a gradient of seagrass (Cymodocea nodosa) colonization. Limnol Oceanogr 49:1642-1651

Bouillon S, Boschker HTS (2006) Bacterial carbon sources in coastal sediments: a cross-system analysis based on stable isotope data of biomarkers. Biogeosciences 3: 175-185

Castaldelli G, Welsh DT, Flachi G, Zucchini G, Colombo G, Rossi R, Fano EA (2003) Decomposition dynamics of the bloom forming macroalga Ulva rigida $\mathrm{C}$. Agardh determined using a ${ }^{14} \mathrm{C}$-carbon radio-tracer technique. Aquat Bot 75:111-122

Cottam C (1934) Past periods of eelgrass scarcity. Rhodora 36:261-264

> Duarte CM, Cebrian J (1996) The fate of marine autotrophic production. Limnol Oceanogr 41:1758-1766

Duarte CM, Middelburg JJ, Caraco N (2005) Major role of marine vegetation on the oceanic carbon cycle. Biogeosciences 2:1-8

Duarte CM, Borum J, Short FT, Walker DI (2008) Seagrass ecosystems: their global status and prospects. In: Polunin NVC (ed) Aquatic ecosystems: trends and global prospects. Cambridge University Press, Cambridge, p 281-294

> Duarte CM, Marbà N, Gacia E, Fourqurean JW, Beggins J, Barrón C, Apostolaki ET (2010) Seagrass community metabolism: assessing the carbon sink capacity of seagrass meadows. Global Biogeochem Cycles 24, GB4032, doi:10.1029/2010GB003793

Duarte CM, Kennedy H, Marbà N, Hendricks I (2013a) Assessing the capacity of seagrass meadows for carbon burial: current limitations and future strategies. Ocean Coast Manage 83:32-38

Duarte CM, Losada IJ, Hendriks IE, Mazarrasa I, Marbà N (2013b) The role of coastal plant communities for climate change mitigation and adaptation. Nat Clim Change 3: 961-968

Dubois S, Savoye N, Grémare A, Plus M, Charlier K, Beltoise A, Blanchet $H$ (2012) Origin and composition of sediment organic matter in a coastal semi-enclosed ecosystem: an elemental and isotopic study at the ecosystem space scale. J Mar Syst 94:64-73

> Fellerhoff C, Voss M, Wantzen KM (2003) Stable carbon and nitrogen isotope signatures of decomposing tropical macrophytes. Aquat Ecol 37:361-375

$>$ Fourqurean JW, Schrlau JE (2003) Changes in nutrient content and stable isotope ratios of $\mathrm{C}$ and $\mathrm{N}$ during decomposition of seagrasses and mangrove leaves along a nutrient availability gradient in Florida Bay, USA. Chem Ecol 19:373-390

- Freudenthal T, Wagner T, Wenzhofer F, Zabel M, Wefer G (2001) Early diagenesis of organic matter from sediments of the eastern subtropical Atlantic: evidence from stable nitrogen and carbon isotopes. Geochim Cosmochim Acta 65:1795-1808

> Fry B (1977) Stable carbon isotope evidence for two sources of organic matter in coastal sediments: seagrasses and plankton. Geochim Cosmochim Acta 41:1875-1877

Fry B (2006) Stable isotope ecology. Springer, New York, NY

- Gacia E, Duarte CM (2001) Sediment retention by a Mediterranean Posidonia oceanica meadow: the balance between deposition and resuspension. Estuar Coast Shelf Sci 52:505-514 
Gacia E, Duarte CM, Middelburg JJ (2002) Carbon and nutrients deposition in a Mediterranean seagrass (Posidonia oceanica) meadow. Limnol Oceanogr 47:23-32

Gonneea ME, Paytan A, Herrera-Silveira JA (2004) Tracing organic matter sources and carbon burial in mangrove sediments over the past 160 years. Estuar Coast Shelf Sci 61:211-227

> Greiner JT, McGlathery KJ, Gunnell J, McKee BA (2013) Seagrass restoration enhances 'blue carbon' sequestration in coastal waters. PLoS One 8:e72469

Hansen JC, Reidenbach MA (2013) Seasonal growth and senescence of a Zostera marina seagrass meadow alters wave-dominated flow and sediment suspension within a coastal bay. Estuaries Coasts 36:1099-1114

> Harrison PG (1989) Detrital processing in seagrass systems: a review of factors affecting decay rates, remineralization and detritivory. Aquat Bot 35:263-288

Hemminga MA, Duarte CM (2000) Seagrass ecology. Cambridge University Press, Cambridge

Hill JM, McQuaid CD (2009) Variability in the fractionation of stable isotopes during degradation of two intertidal red algae. Estuar Coast Shelf Sci 82:397-405

> Hondula KL, Pace ML (2014) Macroalgal support of cultured hard clams in a low nitrogen coastal lagoon. Mar Ecol Prog Ser 498:187-201

Kennedy H, Beggins J, Duarte CM, Fourqurean JW, Holmer M, Marbà N, Middelburg JJ (2010) Seagrass sediments as a global carbon sink: isotopic constraints. Global Biogeochem Cycles 2, GB4026, doi:10.1029/ 2010GB003848

Koch EW, Ackerman JD, Verduin J, van Keulen M (2006) Fluid dynamics in seagrass ecology - from molecules to ecosystems. In: Seagrasses: biology, ecology, and conservation. Springer, Amsterdam, p 193-225

Machás R, Santos R, Peterson B (2006) Elemental and stable isotope composition of Zostera noltii (Horneman) leaves during the early phases of decay in a temperate mesotidal lagoon. Estuar Coast Shelf Sci 66:21-29

Macko SA, Estep MLF (1984) Microbial alteration of stable nitrogen and carbon isotopic compositions of organic matter. Org Geochem 6:787-790

Marbà N, Arias-Ortiz A, Masqué P, Kendrick GA and others (2015) Impact of seagrass loss and subsequent revegetation on carbon sequestration and stocks. J Ecol 103: 296-302

Mateo MA, Cebrain J, Dunton K, Mutchler T (2006) Carbon flux in seagrass ecosystems. In: Larkum AW, Orth RJ, Duarte CM (eds) Seagrasses: biology, ecology and conservation. Springer, New York, NY, p 159-192

McGlathery KJ, Anderson IC, Tyler AC (2001) Magnitude and variability of benthic and pelagic metabolism in a temperate coastal lagoon. Mar Ecol Prog Ser 216:1-15

McGlathery KJ, Christian R, Blum L (2008) VCR LTER Dataset. VCR08144. Water quality of Virginia coastal bays Total suspended solids, particulate inorganic and organic matter. Virginia Coast Reserve. Long term ecological research Project, Charlottesville, VA. http://tropical.lternet.edu:80/knb/metacat?action=read\&docid=knb-ltervcr.155.19\&qformat=lter (accessed 8 Jan 2014)

McGlathery KJ, Reynolds LK, Cole LW, Orth RJ, Marion SR, Schwarzschild A (2012) Recovery trajectories during state change from bare sediment to eelgrass dominance. Mar Ecol Prog Ser 448:209-221

Mcleod E, Chmura GL, Bouillon S, Salm R and others (2011) A blueprint for blue carbon: toward an improved under- standing of the role of vegetated coastal habitats in sequestering $\mathrm{CO}_{2}$. Front Ecol Environ 9:552-560

- Meyers PA, Ishiwatari R (1993) Lacustrine organic geochemistry-an overview of indicators of organic matter sources and diagenesis in lake sediments. Org Geochem 20:867-900

> Middelburg JJ, Barranguet C, Boschker HTS, Herman PMJ, Moens T, Heip CHR (2000) The fate of intertidal microphytobenthos carbon: an in situ ${ }^{13} \mathrm{C}$-labeling study. Limnol Oceanogr 45:1224-1234

Moore JW, Semmens BX (2008) Incorporating uncertainty and prior information into stable isotope mixing models. Ecol Lett 11:470-480

Nellemann C, Corcoran E, Duarte C, Valdés L, De Young C, Fonseca L, Grimsditch G (2009) Blue carbon. A rapid response assessment. United Nations Environment Programme, Arendal

Orem WH, Holmes CW, Kendall C, Lerch HE and others (1999) Geochemistry of Florida Bay sediments: nutrient history at five sites in eastern and central Florida Bay. J Coast Res 15:1055-1071

> Orth RJ, Carruthers TJB, Dennison WC, Duarte CM and others (2006a) A global crisis for seagrass ecosystems. Bioscience 56:987-996

Orth RJ, Luckenbach ML, Marion SR, Moore KA, Wilcox DJ (2006b) Seagrass recovery in the Delmarva Coastal Bays, USA. Aquat Bot 84:26-36

> Orth RJ, Moore KA, Marion SR, Wilcox DJ, Parrish DB (2012) Seed addition facilitates eelgrass recovery in a coastal bay system. Mar Ecol Prog Ser 448:177-195

Papadimitriou S, Kennedy H, Kennedy DP, Duarte CM, Marbà N (2005a) Sources of organic matter in seagrasscolonized sediments: a stable isotope study of the silt and clay fraction from Posidonia oceanica meadows in the western Mediterranean. Org Geochem 36:949-961

Papadimitriou S, Kennedy H, Kennedy DP, Borum J (2005b) Seasonal and spatial variation in the organic carbon and nitrogen concentration and their stable isotopic composition in Zostera marina (Denmark). Limnol Oceanogr 50: 1084-1095

> Pendleton L, Donato DC, Murray BC, Crooks S and others (2012) Estimating global 'blue carbon' emissions from conversion and degradation of vegetated coastal ecosystems. PLoS One 7:e43542

> Peterson BJ, Howarth RW (1987) Sulfur, carbon, and nitrogen isotopes used to trace organic matter flow in the saltmarsh estuaries of Sapelo Island, Georgia. Limnol Oceanogr 32:1195-1213

Phillips DL, Gregg JW (2003) Source partitioning using stable isotopes: coping with too many sources. Oecologia 136:261-269

R Core Team (2012) R: a language and environment for statistical computing. R Foundation for Statistical Computing, Vienna

Rasmussen E (1977) The wasting disease of eelgrass (Zostera marina) and its effects on the environmental factors and fauna. In: McRoy CP, Helfferich C (eds) Seagrass ecosystems - a scientific perspective. Marcel Dekker, New York, NY, p 1-15

> Rheuban JE, Berg P, McGlathery KJ (2014) Ecosystem metabolism along a colonization gradient of eelgrass (Zostera marina) measured by eddy correlation. Limnol Oceanogr 59:1376-1387

Ricart AM, York PH, Rasheed MA, Perez M, Romero J, Bryant CV, Macreadie PI (2015) Variability of sedimen- 
tary organic carbon in patchy seagrass landscapes. Mar Pollut Bull 100:476-482

Riera P, Richard P (1996) Isotopic determination of food sources of Crassostrea gigas along a trophic gradient in the estuarine bay of Marennes-Oléron. Estuar Coast Shelf Sci 42:347-360

Semmens BX, Ward EJ, Moore JW, Darimont CT (2009) Quantifying inter- and intra-population niche variability using hierarchical Bayesian stable isotope mixing models. PLoS One 4:e6187

Solomon CT, Carpenter SR, Clayton MK, Cole JJ and others (2011) Terrestrial, benthic, and pelagic resource use in lakes: results from a three-isotope Bayesian mixing model. Ecology 92:1115-1125

Thayer GW, Parker PL, LaCroix MW, Fry B (1978) The stable

Editorial responsibility: Just Cebrian,

Dauphin Island, Alabama, USA carbon isotope ratio of some components of an eelgrass, Zostera marina, bed. Oecologia 35:1-12

Thomsen MS, McGlathery KJ, Tyler AC (2006) Macroalgal distribution patterns in a shallow, soft-bottom lagoon, with emphasis on the nonnative Gracilaria vermiculophylla and Codium fragile. Estuaries Coasts 29:465-473

Wilkinson GM, Carpenter SR, Cole JJ, Pace ML (2013) Terrestrial support of pelagic consumers: patterns and variability revealed by a multilake study. Freshw Biol 58:2037-2049

Zieman JC, Macko SA, Mills AL (1984) Role of seagrasses and mangroves in estuarine food webs: temporal and spatial changes in stable isotope composition and amino acid content during decomposition. Bull Mar Sci 35:380-392

Submitted: May 26, 2015; Accepted: April 4, 2016

Proofs received from author(s): May 31, 2016 